\title{
Effect of Ethanol Extract of Camellia Sinensis on Salmonella Typhi Infection in Adult Male Rats
}

\author{
Mohammad Zahid Haider ${ }^{1 *}$, Zesmin Fauzia Dewan², Md. Moniruzzaman Khan ${ }^{3}$, Md. Enamul Kabir ${ }^{4}$, Mir Muhammad \\ Shoyeb Shahabuddin ${ }^{5}$, Mohsena Aktar ${ }^{6}$, Joyashish Roy ${ }^{7}$, Farjana Akter ${ }^{8}$ \\ ${ }^{1}$ Associate Professor, Department of Pharmacology, Netrokona Medical College, Netrokona, Bangladesh \\ ${ }^{2}$ Professor and Chairman (Rtd.), Department of Pharmacology, Bangabandhu Sheikh Mujib Medical University, Shahbag, Dhaka, \\ Bangladesh \\ ${ }^{3}$ Associate Professor, Department of Pharmacology, khwaja Yunus Ali Medical College, Sirajganj, Bangladesh \\ ${ }^{4}$ Associate Professor, Department of Community Medicine, Sheikh Hasina Medical College, Jamalpur, Bangladesh \\ ${ }^{5}$ Associate Professor, Department of Pharmacology, Sheikh Hasina Medical College, Jamalpur, Bangladesh \\ ${ }^{6}$ Associate Professor, Department of Pharmacology and therapeutics, Cumilla Medical College, Cumilla, Bangladesh \\ ${ }^{7}$ Assistant Professor, Department of Pharmacology, Comilla Medical College, Cumilla, Bangladesh \\ ${ }^{8}$ Lecturer, Department of Physiology, Colonel Malek Medical College, Manikganj, Bangladesh
}

Article History
Received: 16.12 .2021
Accepted: 25.01 .2022
Published: 31.01 .2022
Journal homepage:
https://www.easpublisher.com
Quick Response Code

Abstract: Background: Typhoid fever, a potentially fatal multisystem illness which is due to infection by Salmonella typhi, is an important health problem in many developing countries including Bangladesh. Investigators from the US Centers for Disease Control and Prevention estimate that there are 21.6 million typhoid cases annually, with the annual incidence varying from 100 to 1000 cases per 100000 population. Objective: To evaluate the effect of ethanol extract of camellia sinensis on salmonella typhi infection in adult male rats. Materials and Methods: Type of study: This was an experimental study. Duration of study: September 2014February 2016. Place of study: Department of Pharmacology, BSMMU, Shahbag, Dhaka, Department of Microbiology, BSMMU, Shahbag, Dhaka, Department of Clinical Pathology, BSMMU, Shahbag, Dhaka, Department of Chemistry, Dhaka University, Dhaka, Bangladesh. Materials: Animals: 84 adult male Long Evan's Norwegian rats were obtained from the animal house of BSMMU. Sample Size Estimation: So, we took six groups and 10 rats in each group. The groups were: Control group (I), Rat infected with $S$. typhi (II), Rat infected with $S$. typhi then treated with ethanolic leaf extracts of CAS (III), Rat given ethanolic extracts of CAS only (IV), Rat infected with $S$. typhi then treated with ciprofloxacin (V), Rat infected with $S$. typhi then treated with both ciprofloxacin and ethanolic extracts of CAS (VI). Adult male rats were taken for this experiment. The number of rat for each group were $10(\mathrm{n}=10)$. Methodology: Preparation of ethanol extract of $\boldsymbol{C}$. sinensis Linn: Home processing Black and Green tea (C. sinensis) was published by the college of Tropical Agriculture and Human resources (2007) which was supported in part by the USDA, agricultural Research Service's pacific Basin, Agricultural Research center and the Department of Research and Development, County of Hawai'I, Japan. i) Collection of C. sinensis leaves: Harvest $10 \mathrm{~kg}$ of fresh tea shoots from Jaflong Tea estates, Sylhet, Bangladesh which have two leaves and a central, needle-like leaf on a sunny morning. The leaves was identified by the National Herborium Mirpur, Dhaka. A DACB accession number was given for the sample. The number was 41151 . For my experimental study $10 \mathrm{~kg}$ young leaves which is mostly available in March-April season was collected from Jaflong tea estates. Results: The presented experiments were carried out with the aim to observe the effect of the ethanol extract of $C$. sinensis upon $S$. typhi induced infection in rats. The in vitro antibacterial activity was assessed by Disc Diffusion Method. Two experiments were carried out with total numbers of 84 adult male rats. Experiment-I was carried out for determining the Median Infectivity dose $50\left(\mathrm{ID}_{50}\right)$ in twenty four rats. During this period, three rats died after administration of $10^{11} \mathrm{cfu} / \mathrm{ml} \mathrm{S}$. typhi suspension. Experiment-II was carried out with total numbers of 60 adult male rats. No rats died during that period. Results of bacterial colony count of stool, relative organ weight of liver and spleen, haematological parameters of WBC, Neutrophil, Lymphocyte, Monocyte, ESR, RBC, Hb and PCV count were presented in the

*Corresponding Author: Mohammad Zahid Haider 
following sections. Representations of Zone of inhibition (ZI) obtained due to the action of CAS against $S$. typhi. The highest ZI was obtained at a concentration of $300 \mathrm{mg} / \mathrm{ml}$. The mean $\pm \mathrm{SD}$ at $300 \mathrm{mg} / \mathrm{ml}$ was $14.67 \pm 1.53 \mathrm{~mm}$. The negative control sector had no zone of inhibition to $0.5 \mathrm{~mm}$ whereas the antibiotic strip showed highest ZI of $25 \mathrm{~mm}$. The lowest ZI was observed at a concentration of 0.4 $\mathrm{mg} / \mathrm{ml}$. The mean $\pm \mathrm{SD}$ at this concentration was $0.33 \pm 0.58 \mathrm{~mm}$. The mean $\pm \mathrm{SD}$ of $0.8 \mathrm{mg} / \mathrm{ml}$ was $1.33 \pm 0.58$. At a concentration of $10^{11} \mathrm{cfu} / \mathrm{ml}, 12 \%$ rats died within 7 days. But at a concentration of $10^{10}$, more than $50 \%$ animals produced signs of infection and none of them died within 7 days. In determining the infectivity dose of $S$. typhi, it took up to 48 hours before the disease set which states that incubation period of $S$. typhi could be 48 hours or more. Thus Median Infectivity Dose 50 $\left(\mathrm{ID}_{50}\right)$ was determined at a concentration of $10^{10} \mathrm{cfu} / \mathrm{ml}$ by the above mentioned experiment. The value is considered to be significant in comparison to group III $(\mathrm{p}<0.05)$. The mean \pm SD of relative organ weight of liver of group VI was not significantly reduced $(p>0.05)$, when compared to group V. Mean \pm SD of relative organ weight of spleen in group I, II, III, IV, V and VI were $0.73 \pm 0.08,0.86 \pm .72$, $0.78 \pm .09,0.72 \pm 0.07,0.73 \pm .07$ and $0.74 \pm 0.06 \mathrm{mg}$ respectively. ANOVA shows significant difference in relative organ weight of spleen between groups $(F=5.292$, $\mathrm{df}=5$ and $\mathrm{p}<0.001)$. The value is considered to be non-significant in comparison to rest of the group. The mean $\pm \mathrm{SD}$ of relative organ weight of group VI was not significantly rised $(\mathrm{p}>0.05)$, when compared to group V. Mean \pm SD of fecal shedding of $S$. typhi on day-7 in group I, II, III, IV, V and VI were $0.00 \pm 0.00$, $20000000 \pm 19663841.61,199000 \pm 223678.84,0.00 \pm 0.00,96 \pm 131.50$ and $18 \pm$ $27.81 \mathrm{cfu} \mathrm{g}^{-1}$ respectively. ANOVA shows significant difference in fecal shedding of $S$. typhi on day-7 between groups $(\mathrm{F}=10.303, \mathrm{df}=5$ and $\mathrm{p}<0.001)$ and within groups $(\mathrm{F}=10.303, \mathrm{df}=54$ and $\mathrm{p}<0.001)$. The mean $\pm \mathrm{SD}$ of the fecal shedding in group I was $0.00 \pm 0.00$. The mean $\pm \mathrm{SD}$ of fecal shedding in group $\mathrm{V}(\mathrm{ST}+\mathrm{CF})$ and VI $(\mathrm{ST}+\mathrm{CF}+\mathrm{CAS})$ were $96 \pm 131.50$ and $18 \pm 27.81 \mathrm{cfu} \mathrm{g}^{-1}$ respectively. Conclusion: The cumulating results of this study suggested that the oral administration of ethanol extract of $C$. sinensis was able to be useful as an effective antimicrobial agent against $S$. typhi as viable supplements of the present range of antibiotics which was clearly revealed by determination of ZI and MIC in vitro study. These occurred possibly by the presence of polyphenolic compounds in $C$. sinensis specially EGCG which might have antibacterial activity against various foodborne pathogenic gram-negative bacteria, including S. typhi. Future studies with different doses of the extract for a longer duration and follow-up for any adverse effect are required to confirm these results.

Keywords: Ethanol Extract, Camellia Sinensis, Salmonella Typhi Infection, Adult Male Rats.

Copyright (C) 2022 The Author(s): This is an open-access article distributed under the terms of the Creative Commons Attribution 4.0 International License (CC BY-NC 4.0) which permits unrestricted use, distribution, and reproduction in any medium for non-commercial use provided the original author and source are credited.

\section{INTRODUCTION}

Typhoid fever, a potentially fatal multisystem illness which is due to infection by Salmonella typhi, is an important health problem in many developing countries including Bangladesh. Investigators from the US Centers for Disease Control and Prevention estimate that there are 21.6 million typhoid cases annually, with the annual incidence varying from 100 to 1000 cases per 100000 population. The global mortality from typhoid have also been revised downwards from 600 000 to 200000 , largely on the basis of regional extrapolations [1]. S. typhi has been a major human pathogen for thousands of years, thriving in conditions of poor sanitation, crowding, and social chaos [2] Salmonella is one of the genera of the Enterobacteriaceae family. Among the Salmonellae of medical importance are $S$. typhi, Salmonella paratyphi A, Salmonella Paratyphi B; which cause typhoid fever, partyphoid A and B fevers respectivey [3, 4] After a few days of bacteraemia, the bacilli localize, mainly in the lymphoid tissue of the small intestine, resulting in typical lesions in the peyer's patches and follicles. These swell at first, then ulcerate and usually heal [5] The overwhelming majority of infections and deaths occurring in developing countries where typhoid fever is endemic (WHO, 1996) [6] associated to peritonitis due to perforation of ulcerated Peyer's patches within the small intestine (Everest et al., 2001).[7] These intestinal complications are due only to Salmonella enterica serotype Typhi. Bacterial resistance to all the three first line antimicrobials (i.e.chloramphenicol, ampicillin and co-trimoxazole) (WHO, 1992) [8] have been reported. It has been observed that $S$. typhi may develop resistance to most of the antibiotics used to cure typhoid fever. Attention is now shifted to the use of antimicrobial agents to cure the disease or to serve as a good source for new antibiotics [9]. Although 
advances in public health and hygiene in association with proper use of novel antibiotics have led to the virtual disappearance of enteric fever (more commonly termed typhoid fever) from much of the developed world, the disease remains endemic in many developing countries [10]. Typhoid is born by infected food and water prevalent mainly in the topical region while the incidence of typhoid fever has declined greatly such as the provision of clean water and good sewerage systems in Europe and in the USA since the early $20^{\text {th }}$ century [11]. Yet the disease remains a serious public-health problem in developing countries [12]. In Bangladesh, Typhoid fever remains an endemic disease in Bangladesh [13]. For treatment, Until mid-1980s, ampicillin, chloramphenicol, or co-trimoxazole were the major drugs. After sporadic outbreaks of chloramphenicol resistant typhoid between 1970 and 1985, many strains of $S$ typhi developed plasmid mediated multidrug resistance against the three primary antimicrobials used (ampicillin, chloramphenicol, and co-trimoxazole [14]. Since then, ciprofloxacin or the third generation cephalosporins (namely, ceftriaxone) have become the first line of treatment for typhoid fever [15]. Chromosomally acquired quinolone resistance in $S$. typhi and $S$. paratyphi has been recently described in various parts of Asia, possibly related to the widespread and indiscriminate use of quinolones [16, 17] In Ceftriaxone-resistant $S$. typhi was detected in Bangladesh in 1999 [18]. Since 1989 outbreaks caused by strains of $\mathrm{S}$. typhi resistant to chloramphenicol, ampicillin, and trimethoprim and with additional resistance to streptomycin, sulfonamides, and tetracyclines have been reported in many developing countries, especially Pakistan [19, 20], and India [21,22,23]. Such strains have been termed multidrug-resistant (MDR). MDR strains have also caused outbreaks of $S$. typhi infections in Bangladesh, [24] several countries in Southeast Asia [25]. Screening was done of some plants of importance in the Ayurvedic system of traditional medicine used in India to treat enteric diseases. Fifty four plant extracts (methanol and aqueous) were assayed for their activity against multi-drug resistant $S$. typhi. Strong antibacterial activity was shown by the methanol extracts of Aegle marmelos, Salmalia malabarica, Punica granatum, Myristica fragrans, Holarrhena antidysenterica, Terminalia arjuna and Triphal (mixture of Emblica officinalis, Terminalia chebula and Terminalia belerica). Moderate antimicrobial activity was shown by Piccorhiza kurruroa, Acacia catechu, Acacia nilotica, Cichorium intybus, Embelia ribes, Solanum nigrum, Carum copticum, Apium graveolens, Ocimum sanctum, Peucedanum graveolens and Butea monosperma [25]. It is in this search for new antimicrobial agents to combat typhoid disease due to resistance developed by $S$. typhi to common antimicrobial agents that search continues to obtain appropriate antimicrobials possing lesser or no toxicity at all. Camellia sinensis L. is one such source which by a few researchers being investigated at present. The probable active principle i.e., the polyphenol present in green tea leaves could be obtained from leaves of $C$. sinensis [26]. Many polyphenols are present in $C$. sinensis leaves like catechins and epigallocatechin gallate. In addition, it contains tocopherols, carotenoids, ascorbic acid (vitamin C), minerals such as chromium, manganese, selenium, or zinc, and other minor phytochemical compounds [27, 28]. Six types of tea made from the leaves of $C$. sinensis including i) green ii) black iii) oolong iv) dark v) white \& vi) yellow tea. This classification was made according to the degree of fermentation and the color of the tea that was produced [29]. Green and yellow teas are nonfermented tea, and oolong and white teas are called semifermented tea, while dark and black teas are fully fermented [30, 31]. Leaf is one of the highest accumulated plant part of compounds such as the polyphenols. People prefer it for therapeutic purpose. It has been assumed that some of the active ingredients inhibit the growth of disease causing microbes when administered either singly or in combination [32]. The natural compound epigallocatechin-3-gallate (EGCG) is an active polyphenolic catechin and accounts for approximately $59 \%$ of the total catechin that could be obtained from the leaves of the $C$. sinensis. Other catechins in include epigallocatechin (EGC) (19\%), epicatechin-gallate (ECG) $(13.6 \%)$ and epicatechin (EC) (6.4\%) [33] The first documented report of an anti-infective effect of $C$. sinensis was made over 100 years ago by the British army surgeon Mc Naught, who suggested that tea killed the organism that causes typhoid fever (S. typhi) and brucellosis (Brucella melitensis) [34]. Toda et al. [35] found that $C$. sinensis extracts could inhibit and kill Staphylococcus aureus, Staphylococcus epidermidis, $S$. typhi, Salmonella typhimurium, Salmonella enteritidis, Shigella flexnari, Shigella dysenteriae, and Vibrio spp., including vibrio cholera. The extracts have been found to be active also against Clostridium spp., Phytopathogens such as Erwinia spp. and Pseudomonas spp. [36]. From the above discussion it is evident that the search for a new antimicrobial agent to combat $S$. typhi infection is still continuing. Previous studies drew definitive conclusion regarding its antibacterial effect against $S$. typhi in vitro. However, no evidence regarding in vivo study is available till now. As Bangladesh is a tropical country where varieties of tea is harvested throughout year due to favourable climate. Therefore the present study has been designed.

\section{Materials AND Methods}

Type of study: This was an experimental study.

Duration of study: September 2014-February 2016.

Place of study: Department of Pharmacology, BSMMU, Shahbag, Dhaka, Department of Microbiology, BSMMU, Shahbag, Dhaka,Department of Clinical Pathology, BSMMU, Shahbag, Dhaka, Department of Chemistry, Dhaka University, Dhaka, Bangladesh. 
Materials: Animals: 84 adult male Long Evan's Norwegian rats were obtained from the animal house of BSMMU. The rats were 8-12 weeks old and weighed between 150-250 g. The rats were housed in standard size metallic cages in a well-ventilated room. The rats were allowed to live at room temperature with 12 hours of light and 12 hours dark schedule. They were given normal rat diet and water ad libitum. For the purpose of identification, all the rats were marked with permanent ink. The rats were acclimatized for 7 days before the commencement of the study in order to be accustomed to new housing, food, water, handlers, cage mates, noises, smells, light cycle and other variables and regaining homeostasis. Throughout the acclimatization period, rats were provided water and normal rat diet by the researcher.

\section{Drugs, Chemicals and Extracts: Preparation of crude extracts of $C$. sinensis for in vivo assay:}

The crude extract of ethanolic $C$. sinensis was reconstituted in sterile distilled water to obtain concentration of $300 \mathrm{mg} / \mathrm{ml}$ [37]. As the highest zone of inhibition was found at this concentration in vitro test and on the basis of the detailed studies on a non-toxic concentration of $300 \mathrm{mg} / \mathrm{kg} /$ day was selected for oral administration of rats.

Chemicals: i) MacConkey agar, Himedia Laboratories Pvt Ltd, India, ii) Mueller Hinton Agar, Himedia Laboratories Pvt Ltd, India, iii) Xylose- Lysine Deoxycholate Agar (XLD), Himedia Laboratories Pvt Ltd, India, iv) MIU Medium Base, Himedia Laboratories Pvt Ltd, v) Citrate Agar, Himedia Laboratories Pvt Ltd, vi) Krigler Iron Agar, Himedia Laboratories Pvt Ltd, vii) Normal saline - Made in the laboratory of department of Pharmacology, BSMMU, ix) Chloroform, x) Streptomycin $1 \mathrm{gm}$ vial, Renata Pharmaceuticals Ltd, Bangladesh

Appliances: UV - V Spectrophotometer - Shimadzu, 1201, Japan,Electronic digital balance - Mettler and Toledo, Switzerland, Rotatory vacuum evaporator, Centrifuge machine - Andreas - Hettich, Germany, Micropipette, Vortex machine, Refrigerator, Hot air oven, Grinding machine, Freeze drying machine, Petridish of different sizes, Ciprofloxacin antibiotic strip, Conical flask, funnel, filter paper, Glass cuvette, pipettes and test tubes of different sizes, Syringes, needles, blades, forceps, scissor, feeding tube, safety rubber gloves, Sysmex XS-4000 I (Automated CBC Analyzer).

\section{Sample Size Estimation:}

So, we took six groups and 10 rats in each group. The groups were: Control group (I), Rat infected with $S$. typhi (II), Rat infected with $S$. typhi then treated with ethanolic leaf extracts of CAS (III), Rat given ethanolic extracts of CAS only (IV), Rat infected with S. typhi then treated with ciprofloxacin (V), Rat infected with $S$. typhi then treated with both ciprofloxacin and ethanolic extracts of CAS (VI). Adult male rats were taken for this experiment. The number of rat for each group were $10(n=10)$.

\section{Methodology: Preparation of ethanol extract of $C$. sinensis Linn:}

Home processing Black and Green tea $(C$. sinensis) was published by the college of Tropical Agriculture and Human resources (2007) which was supported in part by the USDA, agricultural Research Service's pacific Basin, Agricultural Research center and the Department of Research and Development, County of Hawai'I, Japan.

i) Collection of $\boldsymbol{C}$. sinensis leaves: Harvest $10 \mathrm{~kg}$ of fresh tea shoots from Jaflong Tea estates, Sylhet, Bangladesh which have two leaves and a central, needle-like leaf on a sunny morning. The leaves was identified by the National Herborium Mirpur, Dhaka. A DACB accession number was given for the sample. The number was 41151 . For my experimental study $10 \mathrm{~kg}$ young leaves which is mostly available in March-April season was collected from Jaflong tea estates.

ii) Procedure to inactivate the oxidizing enzymes: The oxidizing enzymes (polyphenol oxidase, peroxidase) present in the tea leaves are responsible for turning the leaves dark. This enzymes can break down the tissue chlorophyll, which contributes the green colour. For obtaining green tea, we have to inactivate the oxidizing enzymes by applying heat, generally soon after harvest. Place $1 / 2 \mathrm{~kg}$ tea shoots in a microwave for approximately 2 minutes in an autoclavable plastic bag using level 5. After cooling the plastic bag, remove the cooked tea \& separate the shoots. Then spread them on a soft cloth for about 3 minutes for removing the surface moisture and cooling the leaves. Repeat this procedure for rest of the tea leaves. Making a loose ball by gathering the tea within the muslin cloth and roll it with light pressure for 1 or 2 minutes until it exudes. Then pan-fry the shoots in a bowl shaped frying pan over low heat, tossing them gently for about $1 \frac{1 / 2}{2}$ minutes until the surfaces of the leaves appear dry. Repeat the gathering, rolling, spreading and pan-frying of the shoots until it become slightly crispy texture.

\section{Procedure to obtain $C$. sinensis powder:}

The dehydrated tea leaves was then dried in natural sunlight. The dried material of $C$. sinensis was smashed and grinded into fine powder by a grinding machine. About 2028 gm powder was stored at room temperature in sterile airtight containers until extraction.

\section{Extraction procedure:}

Many researchers reported influence of different extraction solvents. Solvents such as methanol, ethanol, acetone, propranolol and ethyl acetate have been commonly used for the extraction of the phenolics from the fresh product $[38,39]$. The properties of the extracting solvents significantly affected the measured total phenolic content. Very important parameter is 
solvent polarity-higher the polarity, better the solubility of phenolic compounds [40]. The highest extract yields upto $(22.8 \%)$ were obtained with polar alcohol based solvents [41]. Addition of water to ethanol improves extraction rate, but too high water content brought an increased concomitant extraction of other compounds, and then to lower phenol concentration in the extracts [42]. The highest TPC was extracted using 96\% ethanol. This is due to the wide range of phenols that the aqueous ethanol mixtures can dissolve [43]. Furthermore, ethanolic mixtures have acceptability for human consumption models [44]. $2 \mathrm{~g}$ of fresh plant material was dissolved in $15 \mathrm{ml}$ of an appropriate solvent mixture [45] a) $2028 \mathrm{gm}$ dried grinded powder was taken in amber coloured container. It was soaked into 3 liters of $95 \%$ ethanol for 72 hours at room temperature. The whole was then filtered with filter paper. The filtrate was concentrated with the help of rotatory vacuum evaporator at $60^{\circ} \mathrm{C}$ temperature and at rotations of $100 / \mathrm{min}$. About $550 \mathrm{ml}$ of condensed ethanol extract of $C$. sinensis was obtained. b) Condensed extract was freeze dried. Therefore from 10 $\mathrm{kg}$ of $C$. sinensis leaves, 16 gm dry extract was obtained $(0.16 \%)$. c) Dry extract was preserved in amber coloured air-tight glass bottle at $-20^{0} \mathrm{C}$ until preparatioon of suspension with $300 \mathrm{mg}$ extract in $1 \mathrm{ml}$ of distilled water to administer orally the rats as the highest zone of inhibion was found at this concentration in vitro study.

\section{Sacrifice of animals and collection of samples:}

i. Sacrifice of Animals: Rats were sacrificed under light anaesthesia with chloroform by cutting throat with sharp blade as per protocol.

ii. Collection of Blood: Approximately 2-3 ml blood from each rat was collected from the carotid artery in separate clean and dry test tubes containing EDTA with proper identification numbers. Then it was taken to clinical pathology department for haematological analysis by Sysmex XT-4000i.

iii. Collection of Organs: Liver and spleen were dissected out after opening the abdomen by median incision of the rats. All the organs were weighed (after being blotted on filter paper).

\section{Fecal analysis:}

Method described by Paul keilah lunga et al., [46] and Comfort Nkogwe et al., [47] was used to determine the colony count of S. typhi. Food and water ad libitum would be given to the animals before and during the treatment. The extract was administered orally every morning at 9.00 AM. The fecal matter was collected at 10.30 AM on Day $1,4 \& 7$ and was assessed for the stool bacterial density. The extent to which the animals complied with treatment was studied by counting the amount of bacterial colonies in the fecal samples. The following protocol was followed for this:

- $0.10 \mathrm{~g}$ of fecal matter was dissolved in $5 \mathrm{ml}$ of autoclaved distilled water.
- The test tube containing feces was thoroughly mixed by vortex (Vortex mixer, VM-2000, Digisystem, Taiwan) for two minutes and then centrifuged (Labofuge 200, Heracus, Germany) at $700 \mathrm{x} \mathrm{g}$ for 10 minutes. Then supernatum was decanted into sterile labeled test tube containing 1 $\mathrm{ml}$ of normal saline. Then one-tenth serial dilution of the sample was done till it could be established that countable number of colonies were obtained.

- $50 \mu \mathrm{l}$ of the resulting solution (selective enrichment broths such as selenite cystein) was spread on the surface of solidified $0.9 \%$ saline XLD agar in the $35 \mathrm{~mm}$ type petri dish.

- After incubation for $18 \mathrm{~h}$ at $37^{\circ} \mathrm{c}$, the number of colonies following growth of $S$. typhi in each petri dish were counted and recorded.

- The results were presented as the number of colonies per gram of fecal matter per animal.

\section{Biochemical Test for confirmation of $S$. typhi:}

Hydrogen sulphide $\left(\mathrm{H}_{2} \mathrm{~S}\right)$ producing salmonella form pink-red colonies 3-5 $\mathrm{mm}$ in diameter with black centres. It can be presumptively identified biochemically using KIA (Kligler iron agar), Citrate utilization test using Simon's citrate agar and Motility test by using MIU agar. Salmonella species produce a pink-red (alkaline) slope and yellow (acid) butt indicating fermentation of glucose but not lactose. $S$. typhi also produce small amount of blackening due to hydrogen sulphide production. As $S$. typhi does not produce gas from glucose fermentation, there is no cracks in the medium. S. typhi shows negative citrate test by producing no change in colour of medium. They are motile in MIU agar medium [48].

\section{Relative organ weights:}

Method described by Stanley et al., [49] was used to determine the relative organ weight of rat. On seventh day of the infection, all the animals were euthanized by exsanguinations under chloroform anaesthesia. Different organs namely the liver and spleen were carefully dissected out and weighed in grams (absolute organ weight).

\section{Haematological Study:}

The rats were sacrificed and their blood was collected by cervical collection into labelled EDTA bottles. $3 \mathrm{ml}$ blood was collected and kept in $1 \mathrm{x} 3 \mathrm{ml}$ $\mathrm{K}_{3}$ EDTA (anticoagulant) containing testtube. The CBC count was measured by Sysmex XS-4000 i (Automated CBC Analyzer) in the clinical pathology department of BSMMU. This analyzer utilizes the power of fluorescent flow cytometry and hydrodynamic focusing technologies. Fluorescent technology and hydrodynamic focusing enable the XT-4000 i to consistently classify normal WBC, RBC and PLT population from abnormal populations, thereby decreasing the number of manual interventions. The specifications of this system includes i) reliable platform ii) low sample volume requirements iii) 
Sysmex Network Communications system (SNCS) remote monitoring system supporting maximum uptime. 60 samples per hour provides rapid turnover time. The XT-4000 i provides i) the pannel of standard parameters for basic and reliable anaemia screening \& monitoring ii) High quality Haemoglobin analysis iii) RBC \& PLTs are counted by direct current detection method combined with hydrodynamic focusing technology iv) Direct Haematocrit measurement v) Fluorescent technology enables the XT-4000 i to reliably differentiate normal WBC populations from abnormal.

\section{Statistical Analysis:}

Data obtained from biochemical, haematological and faecal findings of the above experiments were analyzed by one way ANOVA followed by Student's unpaired "t" test. The differences between groups were considered highly significant at $\mathrm{p}<0.001$ and significant at $<0.05$. For simplicity, comparisons between each treatment group and its corresponding control group only have been mentioned. The results were presented by Tables and Diagrams
(Bar diagrams). Each bar represented the mean \pm SD values of the results obtained from specific groups of rats. Figures were drawn by using the 'Microsoft Excel' software installed in a personal computer.

\section{RESULTS}

The presented experiments were carried out with the aim to observe the effect of the ethanol extract of $C$. sinensis upon $S$. typhi induced infection in rats. The in vitro antibacterial activity was assessed by Disc Diffusion Method. Two experiments were carried out with total numbers of 84 adult male rats. Experiment-I was carried out for determining the Median Infectivity dose $50\left(\mathrm{ID}_{50}\right)$ in twenty four rats. During this period, three rats died after administration of $10^{11} \mathrm{cfu} / \mathrm{ml} S$. typhi suspension. Experiment-II was carried out with total numbers of 60 adult male rats. No rats died during that period. Results of bacterial colony count of stool, relative organ weight of liver and spleen, haematological parameters of WBC, Neutrophil, Lymphocyte, Monocyte, ESR, RBC, Hb and PCV count were presented in the following sections.

Table-1: Determination of ZI by Disc Diffusion Method: Antibacterial activity of high and low concentration of ethanol extracts of CAS.

\begin{tabular}{|c|c|c|c|c|c|c|c|c|c|}
\hline 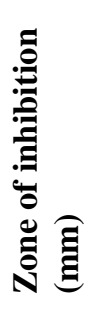 & 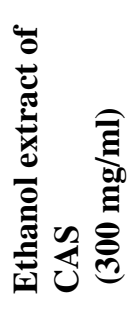 & 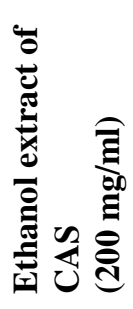 & 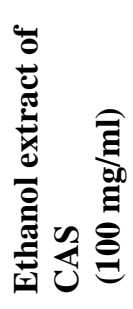 & 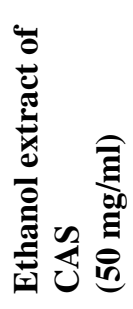 & 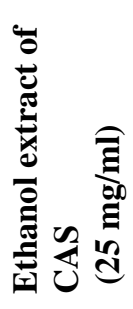 & 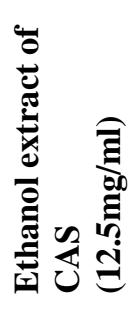 & 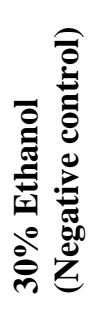 & \multicolumn{2}{|c|}{ 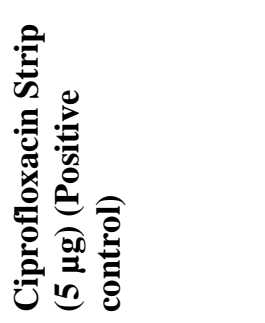 } \\
\hline 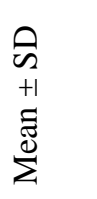 & 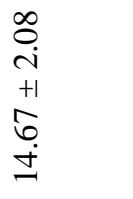 & $\begin{array}{l}\stackrel{n}{n} \\
\stackrel{+}{+1} \\
\stackrel{n}{\dddot{n}} \\
\stackrel{0}{0}\end{array}$ & $\begin{array}{l}8 \\
\stackrel{1}{1} \\
+1 \\
+1 \\
8 \\
\infty \\
\infty\end{array}$ & $\begin{array}{l}8 \\
\\
+1 \\
8 \\
\end{array}$ & $\begin{array}{l}n \\
= \\
+1 \\
+1 \\
b \\
\dot{+}\end{array}$ & $\begin{array}{l}n \\
n \\
+1 \\
\hat{\sigma} \\
\dot{+}\end{array}$ & 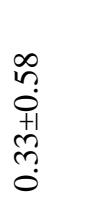 & $\begin{array}{l}\infty \\
n \\
0 \\
+1 \\
\infty \\
m \\
n \\
n\end{array}$ & \\
\hline 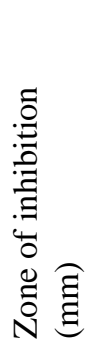 & 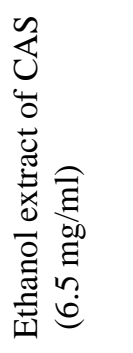 & 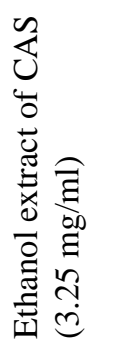 & 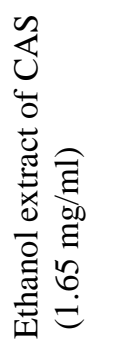 & 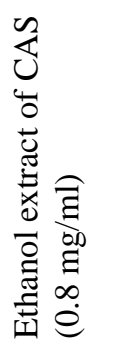 & 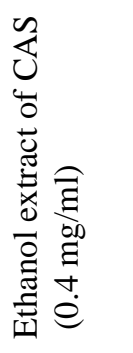 & 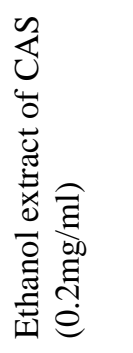 & 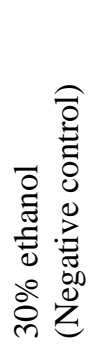 & 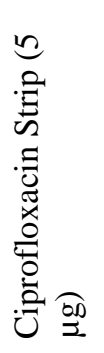 & 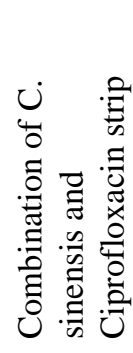 \\
\hline 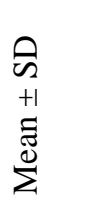 & $\begin{array}{l}\infty \\
n \\
0 \\
+1 \\
m \\
m \\
m\end{array}$ & $\begin{array}{l}\infty \\
n \\
0 \\
+1 \\
m \\
m \\
m\end{array}$ & $\begin{array}{l}8 \\
\dot{8} \\
+1 \\
8 \\
\dot{i}\end{array}$ & 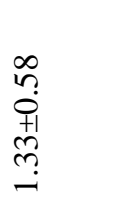 & $\begin{array}{l}\infty \\
n \\
0 \\
+1 \\
m \\
m \\
0\end{array}$ & $\begin{array}{l}8 \\
0 \\
0 \\
+1 \\
8 \\
\dot{0}\end{array}$ & $\begin{array}{l}\infty \\
n \\
0 \\
+1 \\
m \\
m \\
0\end{array}$ & $\begin{array}{l}\infty \\
n \\
0 \\
+1 \\
m \\
m \\
n \\
\end{array}$ & 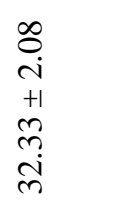 \\
\hline
\end{tabular}




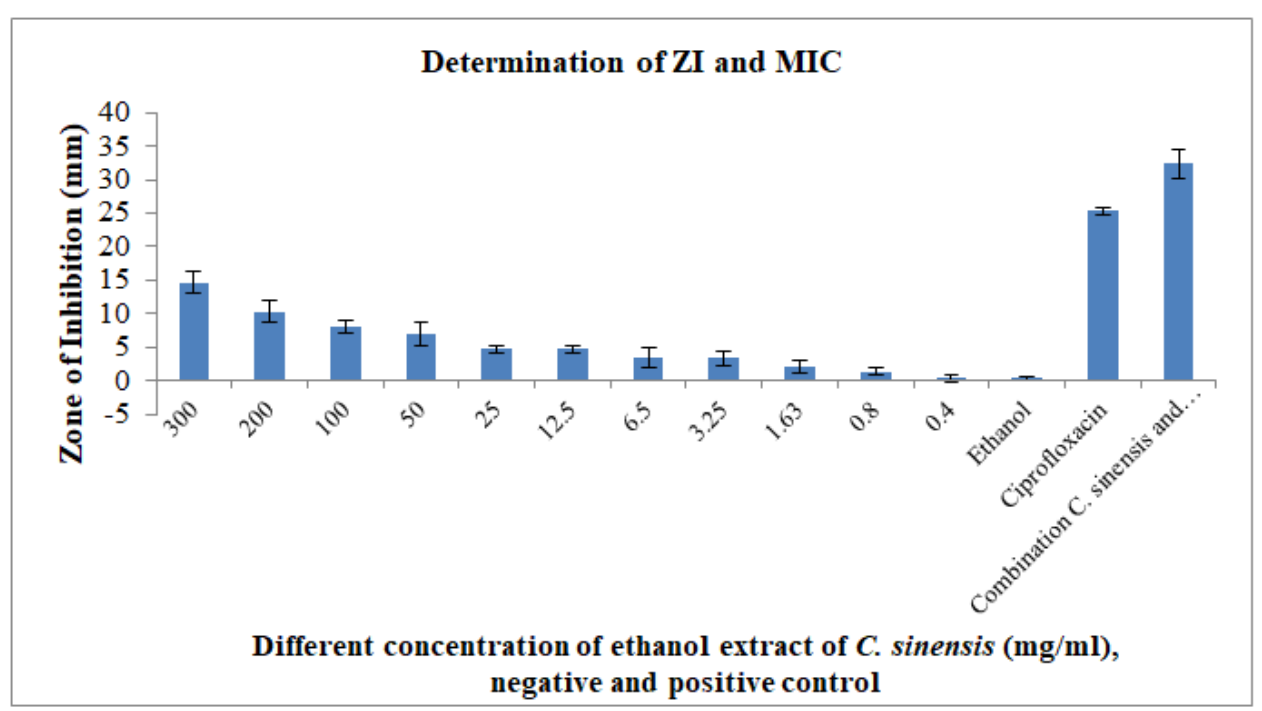

Fig-I: Determination of ZI and MIC by Disc Diffusion Method.

Fig I Represents the Zone of inhibition (ZI) obtained due to the action of CAS against S. typhi. The highest ZI was obtained at a concentration of 300 $\mathrm{mg} / \mathrm{ml}$. The mean $\pm \mathrm{SD}$ at $300 \mathrm{mg} / \mathrm{ml}$ was $14.67 \pm 1.53$ $\mathrm{mm}$. The negative control sector had no zone of inhibition to $0.5 \mathrm{~mm}$ whereas the antibiotic strip showed highest ZI of $25 \mathrm{~mm}$. The lowest ZI was observed at a concentration of $0.4 \mathrm{mg} / \mathrm{ml}$. The mean \pm $\mathrm{SD}$ at this concentration was $0.33 \pm 0.58 \mathrm{~mm}$. The mean $\pm \mathrm{SD}$ of $0.8 \mathrm{mg} / \mathrm{ml}$ was $1.33 \pm 0.58$. There was no $\mathrm{ZI}$ at a concentration of $0.2 \mathrm{mg} / \mathrm{ml}$. As the MIC was defined as the lowest concentration of the extract at which no visible growth was found, the MIC as per this experiment was $0.4-0.8 \mathrm{mg} / \mathrm{ml}$ against $S$. typhi. The combination of $C$. sinensis and ciprofloxacin strip showed highest ZI of $32 \mathrm{~mm}$. Statistical analysis was done by Students unpaired " $\mathrm{t}$ " test when compared to negative control. The concentration of 300 to 3.25 $\mathrm{mg} / \mathrm{ml}$ was considered as highly significant $(\mathrm{p}<0.001)$ whereas the concentration of 1.65 to $0.2 \mathrm{mg} / \mathrm{ml}$ was considered as nonsignificant $(\mathrm{p}>0.05)$.

Table-2: General observation of the $S$. typhi infected rats.

\begin{tabular}{|l|l|l|l|l|l|l|}
\hline Days & Group I & Group II & Group III & Group IV & Group V & Group VI \\
\hline 1 & A, NSI, FS & A, NSI, FS & A, NSI, FS & A, NSI, FS & A, NSI, FS & A, NSI, FS \\
\hline 2 & A, NSI, FS & A, NSI, FS & A, NSI, FS & W, R, C & R, W, FS & R, W, C, , US \\
\hline 3 & A, NSI, FS & A, NSI, FS & A, NSI, FS & W, R, C & R, W, C, FS & R, W, US, FH \\
\hline 4 & A, NSI, FS & A, NSI, FS & R, W, FS & W, R, US & R, W, C, , FH & R, W, US, FH \\
\hline 5 & A, NSI, FS & A, NSI, FS & R, W, FS & W, R, US, FH & R, W, US, FH & R, W, US, FH, D \\
\hline 6 & A, NSI, FS & A, NSI, FS & W, R, C & W, R, US, FH & R, W, US, FH & R, W, US, FH, D \\
\hline 7 & A, NSI, FS & A, NSI, FS & W, R, C & W, R, US, FH & R, W, US, FH & R, W, US, FH, D \\
\hline \multicolumn{6}{c}{ Keys: } \\
A-Active \\
C-Constipation \\
W-Weak \\
R-Restlessness \\
FS-Formed stool \\
D-Dead \\
\cline { 2 - 2 }
\end{tabular}

FH-Falling of hairs

US-Unformed stool

NSI- No sign of infection

From the above experiment, it was observed that less than $50 \%$ rats produced the signs of infectionweakness, unformed stool, diarrhea, furring hair, lose of weight as shown in Table- 3 and plate- 1 respectively at a concentration of $10^{6}, 10^{7}, 10^{8}$ and $10^{9} \mathrm{cfu} / \mathrm{ml}$. Rat feces are usually larger, rectangular with blunt ends. They passes around 40-50 pellets daily and the dropping size is usually $3 / 4$ inch long. The restless rats were characterized by aggressive fur fluffing as the rats motion was very much forward. A weak and ill rat appeared as miserable and down. Rats fur appeared fluffy sticking out almost perpendicular to their body. Rats generally sleep in short bursts of 4 hours, then carry out activities such as feeding, grooming, playing or exploaring to their body. At a concentration of $10^{11}$ $\mathrm{cfu} / \mathrm{ml}, 12 \%$ rats died within 7 days. But at a 
concentration of $10^{10}$, more than $50 \%$ animals produced signs of infection and none of them died within 7 days. In determining the infectivity dose of $S$. typhi, it took up to 48 hours before the disease set which states that incubation period of $S$. typhi could be 48 hours or more. Thus Median Infectivity Dose $50\left(\mathrm{ID}_{50}\right)$ was determined at a concentration of $10^{10} \mathrm{cfu} / \mathrm{ml}$ by the above mentioned experiment.

Table-3: WBC, Neutrophil, Lymphocyte, Hb estimationg/dl), PCV, ESR, RBC, count of rat groups.

\begin{tabular}{|l|l|l|l|l|l|l|}
\hline & Groups I & Groups II & Groups III & Groups IV & Groups V & Groups VI \\
\hline WBC count(x 10\%/L) & 12.28 & 7.08 & 8.98 & 11.39 & 11.56 & 11.14 \\
\hline Neutrophil count (\%) & 48.7 & 39.4 & 44.3 & 52.1 & 48.7 & 49.7 \\
\hline Lymphocyte count (\%) & 36.7 & 46.9 & 41.7 & 39.2 & 36.7 & 33.0 \\
\hline Monocyte count (\%) & 4.0 & 4.5 & 3.5 & 3.7 & 3.8 & 3.8 \\
\hline Hb estimation g/dl) & 13.63 & 10.03 & 11.38 & 14.32 & 13.66 & 14.4 \\
\hline PCV (\%) & 39.99 & 30.06 & 33.71 & 41.06 & 41.05 & 42.53 \\
\hline ESR (mm in 1st hour & 3.8 & 14.4 & 11.7 & 3.8 & 3.2 & 2.7 \\
\hline Mean of RBC count (x 1012/L) & 7.47 & 6.16 & 6.75 & 7.73 & 6.65 & 7.95 \\
\hline
\end{tabular}

Values are expressed as mean $\pm \mathrm{SD}$

$\mathrm{I}=$ Control group $(\mathrm{C}), \mathrm{II}=S$. typhi infected group $(\mathrm{ST}), \mathrm{III}=$ Ethanol extract of $C$. sinensis treated group (ST + CAS), IV $=$ Only Ethanol extract of $C$. sinensis given group (CAS), V = Ciprofloxacin treated group $(\mathrm{ST}+\mathrm{CF}), \mathrm{VI}=$ Concomitantly treated group with ciprofloxacin and ethanol extract of C. sinensis (ST + CF + CAS).

\section{WBC parameters of rats (mean \pm SD)}

Mean \pm SD of WBC count in group I, II, III, IV, $\mathrm{V}$ and VI were $(12.28 \pm 1.72),(7.08 \pm 3.42),(8.95 \pm$ $2.58),(11.39 \pm 0.83),(11.56 \pm 1.04)$ and $(11.14 \pm 0.72)$ $\mathrm{x} 10^{9} / \mathrm{L}$ respectively. ANOVA shows significant difference in between groups $(\mathrm{df}=5, \mathrm{~F}=9.925, \mathrm{p}<0.001)$ and within groups $(\mathrm{df}=54, \mathrm{~F}=9.925, \mathrm{p}<0.001)$. The mean \pm SD of WBC count in group I was $12.28 \pm 1.72$. The mean \pm SD of WBC count was in group $\mathrm{V}(\mathrm{ST}+$ $\mathrm{CF})$ and VI $(\mathrm{ST}+\mathrm{CF}+\mathrm{CAS})$ were $(11.56 \pm 1.04)$ and $(11.14 \pm 0.72) \times 10^{9} / \mathrm{L}$ respectively. There were highly significant rise $(\mathrm{p}<0.001)$, when compared to those of group II. The value is considered to be non-significant in comparison to rest of the group. The mean $\pm \mathrm{SD}$ of WBC count of group VI was not significantly reduced ( $\mathrm{p}>0.10)$, when compared to group $\mathrm{V}$.

\section{Neutrophil count of rats (mean \pm SD)}

Mean \pm SD of Neutrophil count in group I, II, III, IV, V and VI were $(48.70 \pm 8.73),(39.40 \pm 12.36)$, $(44.30 \pm 7.36),(52.10 \pm 5.67),(48.70 \pm 8.73)$ and $(49.70$ $\pm 3.19) \%$ respectively. ANOVA shows significant difference in between groups $(\mathrm{df}=5, \mathrm{~F}=3.11, \mathrm{p}<0.05)$ and within groups $(\mathrm{df}=54, \mathrm{~F}=3.11, \mathrm{p}<0.05)$. The mean \pm $\mathrm{SD}$ of Neutrophil count in group I was $48.70 \pm 8.73$. The mean \pm SD of Neutrophil count was in group V (ST + $\mathrm{CF})$ and VI (ST + CF + CAS) were (48.70 \pm 8.73$)$ and $(49.70 \pm 3.19) \%$ respectively. There were not any significant rise $(p>0.05)$, when compared to those of group I, II, III and IV. The mean \pm SD of Neutrophil count of group VI was not significant rise $(p>0.05)$, when compared to group $\mathrm{V}$.

\section{Lymphocyte count of rats (mean \pm SD)}

Mean \pm SD of Lymphocyte count in group I, II, III, IV, V and VI were (36.70 \pm 3.09$)$, (46.90 \pm 12.67), (41.70 \pm 8.27$),(39.20 \pm 4.02),(36.70 \pm 3.09)$ and $(33.00 \pm 3.43) \%$ respectively. ANOVA shows highly significant difference in between groups $(\mathrm{df}=5$, $\mathrm{F}=5.06, \mathrm{p}<0.001)$ and within groups $(\mathrm{df}=54, \mathrm{~F}=5.06$, $\mathrm{p}<0.001)$. The mean \pm SD of Lymphocyte count in group I was $36.70 \pm 3.09$. The mean \pm SD of Lymphocyte count in group VI (ST + CF + CAS) was $(33.00 \pm 3.43) \%$. There were highly significant reduction $(\mathrm{p}<0.001)$ when compared to that of group II but not any significant reduction in comparison to rest of the group. The mean \pm SD of Lymphocyte count of group VI was not significantly reduced $(p>0.05)$, when compared to group $\mathrm{V}$.

\section{Monocyte count of rats (mean \pm SD)}

Mean \pm SD of Monocyte count in group I, II, III, IV, V and VI were $(04.00 \pm 1.25),(04.50 \pm 1.18)$, $(03.50 \pm 1.27),(03.70 \pm 1.45),(03.80 \pm 0.92)$ and $(03.80$ $\pm 0.92) \%$ respectively. ANOVA shows significant difference in between groups $(\mathrm{df}=5, \mathrm{~F}=0.83, \mathrm{p}>0.05)$ and within groups $(\mathrm{df}=54, \mathrm{~F}=0.83, \mathrm{p}>0.05)$. The mean \pm $\mathrm{SD}$ of Monocyte count in group I was $04.00 \pm 1.25$. The mean $\pm \mathrm{SD}$ of Monocyte count was in group $\mathrm{V}(\mathrm{ST}+$ $\mathrm{CF})$ and VI (ST + CF + CAS) were (3.80 \pm 0.92$)$ and $(03.80 \pm 0.92) \%$ respectively. There were not any significant reduction $(\mathrm{p}>0.05)$, when compared to those of group I, II, III and IV. The mean \pm SD of Monocyte count of group VI was not significantly reduced $(p>0.05)$, when compared to group $\mathrm{V}$.

\section{Estimation of $\mathrm{Hb}$ of rats (mean $\pm \mathrm{SD})$}

Mean \pm SD of Hb estimation in group I, II, III, $\mathrm{IV}, \mathrm{V}$ and VI were $(13.63 \pm 0.77),(10.03 \pm 2.69)$, $(11.38 \pm 2.03),(14.32 \pm 1.36),(13.66 \pm 1.05)$ and $(14.40$ $\pm 0.83) \mathrm{gm} / \mathrm{dl}$ respectively. ANOVA shows significant rise in between groups $(\mathrm{df}=5, \mathrm{~F}=12.24, \mathrm{p}<0.001)$ and within groups $(\mathrm{df}=54, \mathrm{~F}=12.24, \mathrm{p}<0.001)$. The mean \pm $\mathrm{SD}$ of $\mathrm{Hb}$ estimation in group I was $13.63 \pm 0.77$. The mean $\pm \mathrm{SD}$ of $\mathrm{Hb}$ estimation was in group $\mathrm{V}(\mathrm{ST}+\mathrm{CF})$ and VI $(\mathrm{ST}+\mathrm{CF}+\mathrm{CAS})$ were $(13.66 \pm 1.05)$ and $(14.40 \pm 0.83) \mathrm{gm} / \mathrm{dl}$ respectively. There were high significant rise $(\mathrm{p}<0.001)$, when compared to those of group II. The value of group V and VI were considered to be significant $(\mathrm{p}<0.01)$ in comparison to that of group 
III. There were non-significant rise $(p>0.05)$ when compared to that of group I and IV. The mean \pm SD of $\mathrm{Hb}$ count of group VI was not significantly rised ( $>0.05)$, when compared to group V.

\section{Determination of $\mathrm{PCV}$ of rats (mean $\pm \mathrm{SD}$ )}

Mean \pm SD of PCV in group I, II, III, IV, V and VI were $(39.99 \pm 1.18),(30.06 \pm 8.11),(33.71 \pm$ $5.53),(41.06 \pm 1.87),(41.05 \pm 1.36)$ and $(42.53 \pm 5.02)$ $\%$ respectively. ANOVA shows significant difference in between groups $(\mathrm{df}=5, \mathrm{~F}=11.65, \mathrm{p}<0.001)$ and within groups $(\mathrm{df}=54, \mathrm{~F}=11.65, \mathrm{p}<0.001)$. The mean $\pm \mathrm{SD}$ of $\mathrm{PCV}$ in group I was $39.99 \pm 1.18$. The mean $\pm \mathrm{SD}$ of $\mathrm{PCV}$ was in group $\mathrm{V}(\mathrm{ST}+\mathrm{CF})$ and $\mathrm{VI}(\mathrm{ST}+\mathrm{CF}+$ $\mathrm{CAS})$ were $(41.05 \pm 1.36)$ and $(42.53 \pm 5.02) \%$ respectively. There were high significant rise $(\mathrm{p}<0.001)$, when compared to those of group II. The value is considered to be significant $(\mathrm{p}<0.05)$ in comparison to group III but non-significant $(p>0.05)$ rise when compared to that of group I and IV. The mean \pm SD of PCV of group VI was not significantly rised ( $>00.05)$, when compared to group $\mathrm{V}$.

\section{Estimation ESR of rats (mean \pm SD)}

Mean \pm SD of ESR in group I, II, III, IV, V and VI were $(3.80 \pm 1.99),(14.40 \pm 15.22),(11.70 \pm$ $12.42),(3.80 \pm 1.32),(3.20 \pm 1.03)$ and $(2.70 \pm 0.82)$ $\mathrm{mm} / \mathrm{h}$ respectively. ANOVA shows significant difference in between groups $(\mathrm{df}=5, \mathrm{~F}=3.95, \mathrm{p}<0.01)$ and within groups $(\mathrm{df}=54, \mathrm{~F}=3.95, \mathrm{p}<0.01)$. The mean \pm SD of ESR level in group I was $3.80 \pm 1.99$. The mean $\pm \mathrm{SD}$ of ESR was in group V $(\mathrm{ST}+\mathrm{CF})$ and $\mathrm{VI}(\mathrm{ST}+$ $\mathrm{CF}+\mathrm{CAS})$ were $(3.20 \pm 1.03)$ and $(2.70 \pm 0.82) \mathrm{mm} / \mathrm{h}$ respectively. There were significant reduction $(\mathrm{p}<0.05)$, when compared to those of group II. The value is considered to be non-significant in comparison to rest of the group. The mean \pm SD of ESR of group VI was not significantly reduced $(\mathrm{p}>0.05)$, when compared to group V.

\section{RBC count of rats (mean $\pm \mathrm{SD})$}

Mean \pm SD of RBC count in group I, II, III, IV, $\mathrm{V}$ and VI were $(7.47 \pm 0.404),(6.16 \pm 1.99),(6.75 \pm$ $0.99),(7.73 \pm 0.66),(6.65 \pm 0.940)$ and $(7.95 \pm 0.57) \mathrm{x}$ $10^{12} / \mathrm{L}$ respectively. ANOVA shows significant difference in between groups $(\mathrm{df}=5, \mathrm{~F}=4.403, \mathrm{p}<0.01)$ and within groups $(\mathrm{df}=54, \mathrm{~F}=4.403, \mathrm{p}<0.01)$. The mean $\pm \mathrm{SD}$ of RBC count in group I was $7.47 \pm 0.404$. The mean $\pm \mathrm{SD}$ of $\mathrm{RBC}$ count was in group $\mathrm{V}(\mathrm{ST}+\mathrm{CF})$ and VI $(\mathrm{ST}+\mathrm{CF}+\mathrm{CAS})$ were $(6.65 \pm 0.940)$ and $(7.95$ $\pm 0.57) \times 10^{12} / \mathrm{L}$ respectively. There were significant rise of values obtained from group VI $(\mathrm{p}<0.05)$, when compared to those of group II. The value is considered to be non-significant in comparison to rest of the group. The mean \pm SD of RBC count of group VI was not significantly rised $(\mathrm{p}>0.05)$, when compared to group V.

Table-4: Concentration of relative organ weight of liver and organ weight of spleen of rat groups.

\begin{tabular}{|l|l|l|l|l|l|l|}
\hline & Groups I & Groups II & Groups III & Groups IV & Groups V & Groups VI \\
\hline Relative organ weight of liver (mg) & 5.18 & 6.31 & 5.84 & 5.08 & 5.21 & 5.18 \\
\hline Relative organ weight of spleen (mg) & 0.73 & 0.86 & 0.78 & 0.72 & 0.73 & 0.74 \\
\hline
\end{tabular}

Values are expressed as mean \pm SD

Table-5: Relative organ weight of Liver $(\mathrm{mg})$ and organ weight of Spleen $(\mathrm{mg})$ (mean \pm SD).

\begin{tabular}{|l|l|l|l|l|l|l|}
\hline Group & I & II & III & IV & V & VI \\
\hline Relative organ weight of Liver & $5.18 \pm 0.64$ & $6.31 \pm 0.48$ & $5.84 \pm 0.48$ & $5.08 \pm 0.58$ & $5.21 \pm 0.71$ & $5.18 \pm 0.67$ \\
$(\mathrm{mg})$ & & $* * *$ & $* * *, \cdots$ & $\mathrm{NS}_{1}, \cdots$ & $\mathrm{NS}_{1}, \cdots \cdot \cdots, \cdots$ & $\mathrm{NS}_{1}, \cdots, \cdots, \cdots, \mathrm{NS}_{2}$ \\
\hline Relative organ weight of & $0.73 \pm 0.08$ & $0.86 \pm 0.72$ & $0.78 \pm 0.09$ & $0.72 \pm 0.07$ & $0.73 \pm 0.07$ & $0.74 \pm 0.06$ \\
Spleen (mg) & $\mathbf{- \cdot}$ & $* * *, \cdots$ & $\mathrm{NS}_{1}, \mathrm{NS}_{2}$ & $\mathrm{NS}_{1}, \cdots, \cdots, \cdots$ & $\mathrm{NS}_{1}, \cdots \cdot, \cdots$ & $\mathrm{NS}_{1}, \cdots, \cdots, \cdots, \mathrm{NS}_{3}$ \\
\hline
\end{tabular}

$\mathrm{I}=$ Control group $(\mathrm{C})$

$\mathrm{II}=S$. typh $i$ infected group $(\mathrm{ST})$

$\mathrm{III}=$ Ethanol extract of $C$. sinensis treated group $(\mathrm{ST}+\mathrm{CAS})$

$\mathrm{IV}=$ Only Ethanol extract of $C$. sinensis given group (CAS)

$\mathrm{V}=$ Ciprofloxacin treated group $(\mathrm{ST}+\mathrm{CF})$

$\mathrm{VI}=$ Concomitantly treated group with ciprofloxacin and ethanol extract of $C$. sinensis $(\mathrm{ST}+\mathrm{CF}+\mathrm{CAS})$

Values are expressed as mean $\pm \mathrm{SD}$

Data analyzed by oneway ANOVA followed by Student's unpaired " $t$ " test

$* * * \mathrm{p}<0.001$, when compared to control (I) group

$\mathrm{NS}_{1} \mathrm{p}>0.05$, when compared to control (I) group

$\cdots p<0.001$, when compared to $S$. typhi infected group (ST)

$\cdots \mathrm{p}<0.05$, when compared to Ethanol extract of C. sinensis treated group (ST + CAS)

$\mathrm{NS}_{2} \mathrm{p}>0.05$, Ciprofloxacin treated group $(\mathrm{SF}+\mathrm{CF})$ is compared to Concomitantly treated group with ciprofloxacin and ethanol extract of $C$. sinensis $(\mathrm{ST}+\mathrm{CF}+\mathrm{CAS})$ group.

Mean \pm SD of relative organ weight of liver in group I, II, III, IV, V and VI were $5.18 \pm 0.64,6.31 \pm$
$0.48,5.84 \pm 0.48,5.08 \pm 0.58,5.21 \pm 0.71$ and $5.18 \pm$ $0.67 \mathrm{mg}$ respectively. ANOVA shows significant 
difference in relative organ weight of liver between groups $(\mathrm{F}=6.77, \mathrm{df}=5$ and $\mathrm{p}<0.001)$ and within groups $(\mathrm{F}=6.77, \mathrm{df}=54$ and $\mathrm{p}<0.001)$. The mean $\pm \mathrm{SD}$ of relative organ weight of liver in group I (C) was $5.18 \pm$ 0.64 . In group II (ST), the mean $\pm \mathrm{SD}$ of the relative organ weight of liver was $6.31 \pm 0.48 \mathrm{mg}$, which a highly significant rise $(\mathrm{p}<0.001)$ when compared to that of group I, suggesting that rats of group II were probably infected by $S$. typhi. In group III (ST + CAS), the mean $\pm \mathrm{SD}$ of the same was $5.84 \pm 0.48 \mathrm{mg}$. There was significant rise $(p<0.01)$ between the values obtained from group I and IV. There is also significant reduction $(\mathrm{p}<0.05)$ of relative organ weight of liver in this group when compared to group II.

In group IV (CAS), the mean $\pm \mathrm{SD}$ of the relative organ weight of liver was $5.08 \pm 0.58 \mathrm{mg}$. There was not significant reduction $(p>0.05)$ of this marker, compared to that of group I. But in comparison to group II and III, this reduction is significant $(\mathrm{p}<0.05)$. The mean \pm SD of relative organ weight of liver in group V $(\mathrm{ST}+\mathrm{CF})$ and VI $(\mathrm{ST}+\mathrm{CF}+\mathrm{CAS})$ were 5.21 \pm 0.71 and $5.18 \pm 0.67 \mathrm{mg}$ respectively. There were highly significant reduction $(\mathrm{p}<0.001)$ when compared to those of group II. The value is considered to be significant in comparison to group III $(p<0.05)$. The mean \pm SD of relative organ weight of liver of group VI was not significantly reduced $(\mathrm{p}>0.05)$, when compared to group V. Mean \pm SD of relative organ weight of spleen in group I, II, III, IV, V and VI were $0.73 \pm 0.08$, $0.86 \pm .72,0.78 \pm .09,0.72 \pm 0.07,0.73 \pm .07$ and 0.74 $\pm 0.06 \mathrm{mg}$ respectively. ANOVA shows significant difference in relative organ weight of spleen between groups $(\mathrm{F}=5.292, \mathrm{df}=5$ and $\mathrm{p}<0.001)$. The mean $\pm \mathrm{SD}$ of the relative organ weight of spleen in group I was 0.73 \pm 0.08 . The mean $\pm \mathrm{SD}$ of relative organ weight of spleen in group $\mathrm{V}(\mathrm{ST}+\mathrm{CF})$ and $\mathrm{VI}(\mathrm{ST}+\mathrm{CF}+\mathrm{CAS})$ were $0.73 \pm 0.07$ and $0.74 \pm 0.06$ respectively. There were highly significant reduction $(\mathrm{p}<0.05)$, when compared to those of group II. The value is considered to be non-significant in comparison to rest of the group. The mean \pm SD of relative organ weight of group VI was not significantly rised ( $p>0.05)$, when compared to group V.

Table-7: Faecal shedding of S. typhi on Day-1, Day-4 and Day-7.

\begin{tabular}{|l|l|l|l|l|}
\hline $\begin{array}{l}\text { No of } \\
\text { groups }\end{array}$ & Groups & Day 1 & Day 4 & Day 7 \\
\hline I & Control (C) & 0 & 0 & 0 \\
\hline II & Rat infected with S. typhi (ST) & 1640000 & 7130000 & 20000000 \\
\hline III & $\begin{array}{l}\text { Rat infected with Salmonella then treated with ethanolic leaf } \\
\text { extracts of CAS (ST+CAS) }\end{array}$ & 2320000 & 679000 & 199000 \\
\hline IV & Rat given ethanolic extracts of CAS only (CAS) & 0 & 0 & 0 \\
\hline V & $\begin{array}{l}\text { Rat infected with Salmonella then treated with ciprofloxacin } \\
\text { (ST+CF) }\end{array}$ & 2100000 & 1830 & 96 \\
\hline VI & $\begin{array}{l}\text { Rat infected with Salmonella then treated with both ciprofloxacin } \\
\text { and ethanolic extracts of CAS(ST+CF+CAS) }\end{array}$ & 2310000 & 1430 & 18 \\
\hline
\end{tabular}

Table-8: Faecal shedding of S. typhi on Day-1, Day-4 and Day-7 (Mean \pm SD).

\begin{tabular}{|c|c|c|c|c|c|c|}
\hline Group & I & II & III & IV & V & VI \\
\hline $\begin{array}{l}\text { Mean } \pm \\
\text { SD, Day- } \\
7\end{array}$ & $\begin{array}{l}0.00 \pm \\
0.00 \\
\bullet \bullet, \mathrm{NS}_{2}\end{array}$ & $\begin{array}{l}20000000 \pm \\
19663841.61 * * * \ldots\end{array}$ & $\begin{array}{l}199000 \pm \\
223678.84 \\
\mathrm{NS}_{1}, \bullet \bullet\end{array}$ & $\begin{array}{l}0.00 \pm 0.00 \\
\mathrm{NS}_{1}, \bullet \bullet, \mathrm{NS}_{2}\end{array}$ & $\begin{array}{l}96 \pm 131.50 \\
\mathrm{NS}_{1}, \bullet \bullet, \mathrm{NS}_{2}\end{array}$ & $\begin{array}{l}18 \pm 27.81 \\
\mathrm{NS}_{1}, \bullet \bullet \bullet, \mathrm{NS}_{2}, \mathrm{NS}_{3}\end{array}$ \\
\hline $\begin{array}{l}\text { Mean } \pm \\
\text { SD Day- } \\
4\end{array}$ & $\begin{array}{l}0.00 \pm \\
0.00 \\
\bullet \bullet, \mathrm{NS}_{2}\end{array}$ & $\begin{array}{l}7130000 \pm \\
7074845.90 \\
* * *, . .\end{array}$ & $\begin{array}{l}679000 \pm \\
718400.23 \\
\mathrm{NS}_{1}, \cdots \bullet\end{array}$ & $\begin{array}{l}0.00 \pm 0.00 \\
\mathrm{NS}_{1}, \bullet \bullet \bullet, \mathrm{NS}_{2}\end{array}$ & $\begin{array}{l}1830.00 \pm \\
2148.41 \\
\mathrm{NS}_{1}, \cdot \bullet \bullet, \mathrm{NS}_{2}\end{array}$ & $\begin{array}{l}1430 \pm 21150.05 \\
\mathrm{NS}_{1}, \bullet \bullet, \mathrm{NS}_{2}, \mathrm{NS}_{3}\end{array}$ \\
\hline $\begin{array}{l}\text { Mean } \pm \\
\text { SD Day- } \\
1\end{array}$ & $\begin{array}{l}0.00 \pm \\
0.00 \\
\mathrm{NS}_{2,}, \cdot \cdot \\
\end{array}$ & $\begin{array}{l}1640000 \pm \\
1947762.25 \\
\mathrm{NS}_{1}, \mathrm{NS}_{3} \\
\end{array}$ & $\begin{array}{l}2320000 \pm \\
1957208.90 \\
* * *, \mathrm{NS}_{2}\end{array}$ & $\begin{array}{l}0.00 \pm 0.00 \\
\mathrm{NS}_{1}, \mathrm{NS}_{2}, \cdot \cdot \cdot\end{array}$ & $\begin{array}{l}2100000 \pm \\
1992207.04 \\
\mathrm{NS}_{1}, \mathrm{NS}_{2}, \mathrm{NS}_{3}\end{array}$ & $\begin{array}{l}2310000 \pm \\
2175341.61 \\
* * *, \mathrm{NS}_{2}, \mathrm{NS}_{3}, \mathrm{NS}_{4}\end{array}$ \\
\hline
\end{tabular}

Values are expressed as mean $\pm \mathrm{SD}$.

Mean \pm SD of fecal shedding of $S$. typhi on day-1 in group I, II, III, IV, V and VI were $0.00 \pm 0.00$, $1640000 \pm 1947762.25,2320000 \pm 1957208.90,0.00 \pm$ $0.00,2100000 \pm 1992207.04$ and $2310000 \pm$ $2175341.61 \mathrm{cfu}^{-1}$ respectively. ANOVA shows significant difference in fecal shedding of $S$. typhi on day-1 between groups $(\mathrm{F}=4.515, \mathrm{df}=5$ and $\mathrm{p}<0.01)$ and within groups $(\mathrm{F}=4.515, \mathrm{df}=54$ and $\mathrm{p}<0.01)$. The mean $\pm \mathrm{SD}$ of the fecal shedding in group $\mathrm{I}$ was $0.00 \pm$ 0.00 .The mean $\pm \mathrm{SD}$ of fecal shedding in group V (ST
$+\mathrm{CF})$ and VI (ST + CF + CAS) were $2100000 \pm$ 1992207.04 and $2310000 \pm 2175341.61 \mathrm{cfu}^{-1}$ respectively. The value obtained from group VI was significant $(\mathrm{p}<0.05)$, when compared to those of group I and IV. The value is considered to be non-significant ( $p>0.05)$ in comparison to rest of the group. The value obtained from group $\mathrm{V}$ was non-significant $(\mathrm{p}>0.05)$ when compared to group I, II, III, IV and VI. The mean \pm SD of fecal shedding of group VI was not 
significantly changed $(\mathrm{p}>0.05)$, when compared to group $\mathrm{V}$.

Mean \pm SD of fecal shedding of $S$. typhi on day-4 in group I, II, III, IV, V and VI were $0.00 \pm 0.00$, $7130000 \pm 7074845.90,679000 \pm 718400.23,0.00 \pm$ $0.00,1830.0000 \pm 2148.41$ and $1430 \pm 21150.05 \mathrm{cfu} \mathrm{g}^{-1}$ respectively. ANOVA shows significant difference in fecal shedding of $S$. typhi on day-4 between groups $(\mathrm{F}=9.759, \mathrm{df}=5$ and $\mathrm{p}<0.001)$ and within groups $(\mathrm{F}=9.759$, df $=54$ and $\mathrm{p}<0.001)$. The mean $\pm \mathrm{SD}$ of the fecal shedding in group I was $0.00 \pm 0.00$. The mean \pm $\mathrm{SD}$ of fecal shedding in group $\mathrm{V}(\mathrm{ST}+\mathrm{CF})$ and VI (ST $+\mathrm{CF}+\mathrm{CAS})$ were $1830.0000 \pm 2148.41$ and $1430 \pm$ $21150.05 \mathrm{cfu} \mathrm{g}^{-1}$ respectively. The value obtained from group V and VI was highly significant rise $(p<0.001)$, when compared to those of group II .The value is considered to be non-significant ( $p>0.05$ ) in comparison to rest of the group. The mean $\pm \mathrm{SD}$ of fecal shedding of group VI was not significantly reduced $(p>0.05)$, when compared to group $\mathrm{V}$.

Mean \pm SD of fecal shedding of $S$. typhi on day-7 in group I, II, III, IV, V and VI were $0.00 \pm 0.00$, $20000000 \pm 19663841.61,199000 \pm 223678.84,0.00 \pm$ $0.00,96 \pm 131.50$ and $18 \pm 27.81$ cfu g $^{-1}$ respectively. ANOVA shows significant difference in fecal shedding of $S$. typhi on day-7 between groups $(\mathrm{F}=10.303, \mathrm{df}=5$ and $\mathrm{p}<0.001)$ and within groups $(\mathrm{F}=10.303, \mathrm{df}=54$ and $\mathrm{p}<0.001)$. The mean $\pm \mathrm{SD}$ of the fecal shedding in group I was $0.00 \pm 0.00$. The mean $\pm \mathrm{SD}$ of fecal shedding in group $\mathrm{V}(\mathrm{ST}+\mathrm{CF})$ and $\mathrm{VI}(\mathrm{ST}+\mathrm{CF}+$ $\mathrm{CAS})$ were $96 \pm 131.50$ and $18 \pm 27.81 \mathrm{cfu} \mathrm{g}^{-1}$ respectively. The value obtained from group $\mathrm{V}$ and $\mathrm{VI}$ were highly significant reduction $(\mathrm{p}<0.001)$, when compared to those of group II. The value is considered to be non-significant $(\mathrm{p}>0.05)$ in comparison to rest of the group. The mean \pm SD of fecal shedding of group VI was not significantly reduced $(p>0.05)$, when compared to group $\mathrm{V}$.

\section{DisCUSSION}

The present study was aimed to evaluate the ameliorative effect of ethanol extract of $C$. sinensis in $S$. typhi infection. Ethanol extract of $C$. sinensis was administered at a dose of $300 \mathrm{mg} / \mathrm{kg} /$ day to adult male Long Evans rats (weighing 150-250 g) for 7 days either alone or with Ciprofloxacin as concomitant regimen. $S$. typhi infection and the ameliorating effects of the treated groups were assessed by fecal analysis, haematological findings and determination of relative organ weight. In the present study, the ethanol extract of $C$. sinensis exhibited antibacterial activity against $S$. typhi. The highest ZI was obtained at a concentration of $300 \mathrm{mg} / \mathrm{ml}$. The negative control sector had no zone of inhibition to $1 \mathrm{~mm}$ whereas the antibiotic strip showed highest ZI of $25 \mathrm{~mm}$. The lowest ZI was observed at a concentration of $0.4 \mathrm{mg} / \mathrm{ml}$ whereas no $\mathrm{ZI}$ at a concentration of $0.2 \mathrm{mg} / \mathrm{ml}$. As the MIC was defined as the lowest concentration of the extract at which no visible growth was found, the MIC as per this experiment was $0.4-0.8 \mathrm{mg} / \mathrm{ml}$ against $S$. typhi. The MICs of $S$. typhi isolates were between $400 \mu \mathrm{g} / \mathrm{ml}$ and $600 \mu \mathrm{g} / \mathrm{ml}$ (Mandal et al., [50] Tiwari et al., [51] showed wide differences in the MIC (9.089-94.61 $\mathrm{mg} / \mathrm{ml}$ ) of $C$. sinensis extract against different bacterial strains including $S$. typhi with MICs of 79.56-91.98 $\mathrm{mg} / \mathrm{ml}$. Pranali et al., [52] found ZI 10-13 mm. Hossain et al., [53] showed that MIC and MBC values were 250 $\mu \mathrm{g} / \mathrm{ml}$ and $1.6 \mathrm{mg} / \mathrm{ml}$ respectively. Yoda et al., [54] showed MICs > $100 \mu \mathrm{g} / \mathrm{ml}$ against $S$. typhi. The differences in antibacterial activities of ethanol extract of $C$. sinensis were probably due to the degrees of susceptibility of cell wall of test bacterial strains, types of solvent used in the extract preparation and different methodology adopted in the determination of antibacterial activity[55]. The polyphenolic compounds including catechins, mainly epigallocatechin-3 gallate, theaflavins and the combination of flavor compounds of C. sinensis are responsible to provide marked antibacterial effects [56, 57]. For the determination of infectivity dose, it took up to 48 hours as it was stated by Prescott et al., [58]. It was found that $50 \%$ rats produced the signs of infection- weakness, unformed stool, diarrhea, furring hair, loss of weight as shown in Table-3 and plate-1 respectively at a concentration of $10^{6}, 10^{7}, 10^{8}$ and $10^{9} \mathrm{cfu} / \mathrm{ml}$. At a concentration of $10^{11}$ $\mathrm{cfu} / \mathrm{ml}, 12 \%$ rats died within 7 days. But at a concentration of $10^{10}$, more than $50 \%$ animals produced signs of infection and none of them died within 7 days. In determining the infectivity dose of $S$. typhi, it took up to 48 hours before the disease set which states that incubation period of $S$. typhi could be 48 hours or more. Thus Median Infectivity dose $50\left(\mathrm{ID}_{50}\right)$ was determined at a concentration of $10^{10} \mathrm{cfu} / \mathrm{ml}$ by the above mentioned experiment which was previously done by Akinyemi \& Dada et al [59]. The infectivity dose was found $5 \times 10^{14}$ which differed from the present study probably due to variable bacterial strains. Weakness, falling of hairs, passing of unformed stools, furring of hairs and lose of weight were found in rats due to $S$. typhi infection [48]. Rats of group I (Control) were given normal rat diet and water ad libitum and sacrificed on $8^{\text {th }}$ day. The effect on packed cell volume, haemoglobin concentration ( $\mathrm{Hb}$ ), Red blood cell (RBC), Total and differential count of white blood cell (WBC), ESR, count of amount of bacterial colonies in the faecal samples and the relative organ weight of liver and spleen were observed. There was no functional or structural changes observed in control rats. Highly significant reduction of $\mathrm{WBC}, \mathrm{Hb}$ and $\mathrm{PCV}$ count were observed in $S$. typhi infected group where as significant reduction of neutrophil count was found in that group possibly due to the $S$. typhi infection. There were significant rise of lymphocyte and ESR count were observed in that group. There were significant rise of $\mathrm{WBC}$, neutrophil, $\mathrm{Hb}$ and PCV count were found in treated group of ethanol extract of $C$. sinensis group, ciprofloxacin treated group and concomitantly treated group with ciprofloxacin and ethanol extract of $C$. 
sinensis group. Significant reduction of Lymphocyte and ESR were observed in treated groups. There were not any significant effect on RBC and Monocyte count in infected and treated groups. The $C$. sinensis treated group exerted the similar effects on haematological parameters when compared to ciprofloxacin treated group and concomitantly treated group with ciprofloxacin and ethanol extract of $C$. sinensis group . The ethanolic extract of $C$. sinensis had no toxicological effect on the blood parameters compare to control group rather there was increase in Neutrophil and lymphocyte count. The antibacterial effect of ethanol extract of Parquetina nigrescens and Punica granatum peel ethanol extract against $S$. typhi exhibited the similar results. Only differences was found on ESR value. There was no significant differences in ESR in all the groups compare to control $[59,60]$. The rises in WBC count were supposed to be produced during infection due to phagocytosis. But the unexpected reduction in WBC count was observed in S. typhi infection due to the production of coagulase enzyme [61]. This enzyme converts the soluble fibrin to insoluble fibrinogen and helps in blood clotting. Thus it protects from phagocytosis by forming protective coat around the cell of the bacterium [62]. The neutrophil count was reduced and lymphocyte higher in infected than the treated groups. When a chemotactic factor is produced in an intracellular site as a result of infection, the most abundant circulating granulocyte i.e. neutrophil enter the tissues [63]. The lymphocyte count was higher in infected group. The possible cause was due to the presence of only freely circulating leucocyte i. e. lymphocyte after migration of neutrophil into tissues during infection. The significant reduction of lymphocyte in treated group was due to the in vivo antibacterial activity of the extract against $S$. typhi [63]. $\mathrm{The} \mathrm{Hb}$ and PCV count were lower in infected group due to haemolysis caused by most pathogenic microorganisms in acute inflammation [64]. The higher values of these parameters in treated groups were due to their inability to cause haemolysis resulting from the anti-inflammatory potentials of the ethanol extracts of C. sinensis [62]. There was no significant differences in monocyte count in infected and treated groups because monocyte stay for 8 hours in the blood after production before transporting to the parts of the body where they take residents as macrophages [65]. The only ethanolic extracts of $C$. sinensis given group (III) showed increase in neutrophil and lymphocyte count. The possible mechanism could be as a result of high carbohydrate and ascorbic acid content in ethanolic extract of $C$. sinensis as shown by phytochemical screening result $[33,66]$. There was marked increase of relative organ weight of liver in $S$. typhi infected group as a result of $S$. typhi infection [48]. Significant reduction were observed in treated group of ciprofloxacin treated group and concomitantly treated group with ciprofloxacin and ethanol extract of $C$. sinensis group. The reduction in relative organ weight of liver was non-significant in ethanol extract of $C$. sinensis treated group when compared to infected group II. Significant rise of relative organ weight of spleen was observed in $S$. typhi infected group as a result of $S$. typhi infection [48]. Slight reduction were found in treated group of ethanol extract of $C$. sinensis treated group, ciprofloxacin treated group and concomitantly treated group with ciprofloxacin and ethanol extract of C. sinensis group. The normal size of liver and spleen obtained in treated group compare with control is due to the in vivo antibacterial activity of the ethanol extract of $C$. sinensis against $S$. typhi. Treatment with the ethanol extract of $C$. sinensis, Ciprofloxacin and concomitant administration of $C$. sinensis and ciprofloxacin was found to have marked effects on mortality and on the number of viable $S$. typhi recovered from feces. At Day 1 post-infection, ten rats in the $\mathrm{ST}, \mathrm{ST}+\mathrm{CAS}, \mathrm{ST}+\mathrm{CF}$ and $\mathrm{ST}+\mathrm{CF}+\mathrm{CAS}$ groups shed viable $S$. typhi. The feces of rats in the ST group was found to contain at a concentration of $2 \times 10^{5}$ to $5 \times 10^{7} \mathrm{cfu} \mathrm{g}^{-1}$. There was not any significant reduction of bacterial colony count in the treated groups on day 1 post-infection. At Day 4 post-infection, Highly significant rise of bacterial colony count in the feces of ST group and significant reduction of colony count in the treated groups. Marked reduction of colony count were observed in group $\mathrm{ST}+$ $\mathrm{CF}$ and $\mathrm{ST}+\mathrm{CF}+\mathrm{CAS}$. Concomitant administration of Ciprofloxacin and $C$. sinensis showed the highest ameliorating effect. Only Camellia treated group did not produce any significant reduction of colony count in feces in comparison to ciprofloxacin treated group and concomitantly treated group with ciprofloxacin and ethanol extract of $C$. sinensis group. At Day 7 postinfection, similar results were observed as found in Day 4 post-infection. Thus $C$. sinensis exerts antibacterial activity due to its polyphenolic components mainly catechins including epigallocatechin-3-gallate (EGCG), epigallocatechin (EGC), Epicatechin gallate (ECG) and epicatechin (EC) [33]. It was demonstrated that the morphological changes of gram-negative bacterial cell walls induced by EGCG depend on $\mathrm{H}_{2} \mathrm{O}_{2}$ release. One EGCG molecule can produce up to two molecules of $\mathrm{H}_{2} \mathrm{O}_{2}$ in phosphate buffer at neutral $\mathrm{pH}$ [67]. EGCG induces bacteriocidal effect against gram negative bacteria by producing $\mathrm{H}_{2} \mathrm{O}_{2}$ level which causes oxidative stress. The combined use of $C$. sinensis and antibiotics could be useful against multi-drug resistant pathogen especially among enteropathogens.

\section{CONCLUSION}

The cumulating results of this study suggested that the oral administration of ethanol extract of $C$. sinensis was able to be useful as an effective antimicrobial agent against $S$. typhi as viable supplements of the present range of antibiotics which was clearly revealed by determination of ZI and MIC in vitro study. These occurred possibly by the presence of polyphenolic compounds in $C$. sinensis specially EGCG which might have antibacterial activity against various foodborne pathogenic gram-negative bacteria, including S. typhi. Future studies with different doses of the 
extract for a longer duration and follow-up for any adverse effect are required to confirm these results.

\section{LIMITATION \& RECOMMENDATIONS}

The present study due to time constraints, did not attempt to identify any ingredients for its antimicrobial effects. It was not possible for determination of MIC by Disc Dilution Method due to time constraints, which might give the better result instead of Disc Diffusion Method.

Future study is required to improve the bioavailability of the active ingredients, specific mechanism of action and to determine desired dose as well as toxicity before those can be used as therapeutic agents. Further synergistic combinations of the Camellia sinensis extract with conventional antimicrobial agents or with other plant extracts might even improve its therapeutic property. It is being suggested that antimicrobial effects might not be impossible.

\begin{tabular}{|c|c|}
\hline \multicolumn{2}{|c|}{ Abbreviations: } \\
\hline ANOVA & One way analysis of variance \\
\hline BSMMU & Bangabandhu Sheikh Mujib Medical \\
\hline \multicolumn{2}{|l|}{ University } \\
\hline $\mathrm{C}$ & Control \\
\hline CAS & Ethanol extracts of Camellia sinensis \\
\hline $\mathrm{CF}$ & Ciprofloxacin \\
\hline CFU & Colony forming unit \\
\hline CLSI & Clinical and Laboratory Standard Institute \\
\hline C. sinensis & Camellia sinensis \\
\hline $\mathrm{EC}$ & Epicatechin \\
\hline EDTA & Ethyline diamine tetraacedic acid \\
\hline ECG & Epicatechin gallate \\
\hline EGC & Epigallocatechin \\
\hline EGCG & Epigallocatechin-3-gallate \\
\hline EUCAST & European Committee on \\
\hline \multicolumn{2}{|c|}{ Antimicrobial Susceptibility Testing } \\
\hline ESR & Erythrocyte sedimentation rate \\
\hline GA & Gallic acid \\
\hline gm & Gram \\
\hline $\mathrm{Hb}$ & Haemoglobin \\
\hline $\mathrm{ID}_{50}$ & Median Infectivity Dose (50) \\
\hline MIC & Minimum Inhibitory Concentration \\
\hline $\mathrm{MBC}$ & Minimum Bactericidal Concentration \\
\hline $\mathrm{mg}$ & Milligram \\
\hline MHA & Mueller-Hinton Agar \\
\hline $\mathrm{mm}$ & Millimeter \\
\hline PCV & Packed cell volume \\
\hline PLTs & Platelets \\
\hline $\mathrm{RBC}$ & Red blood cell \\
\hline ST & Salmonella typhi infected group \\
\hline S. typhi & Salmonella typhi \\
\hline WBC & White blood cell \\
\hline ZI & Zone of Inhibition \\
\hline
\end{tabular}

\section{REFERENCES}

1. Abdelrahim, S. I., Almagboul, A. Z., Omer, M. E. A., \& Elegami, A. (2002). Antimicrobial activity of Psidium guajava L. Fitoterapia, 73(7-8), 713-715.

2. Papagrigorakis, M. J., Synodinos, P. N., \& Yapijakis, C. (2007). Ancient typhoid epidemic reveals possible ancestral strain of Salmonella enterica serovar Typhi. Infection, Genetics and Evolution, 7(1), 126-127.

3. Ammah, A., Nkuo-Akenji, T., Ndip, R., \& Deas, J. E. (1999). An update on concurrent malaria and typhoid fever in Cameroon. Transactions of the Royal Society of Tropical Medicine and Hygiene, 93(2), 127-129.

4. Adebayo, H. A., Aliyu, R., Gatsing, D., \& Garba, H. I. (2006). The effects of ethanolic leaf extract of Commiphora africana (Burseraceae) on lipid profile in rats. International Journal of pharmacology,2(6), 618-622.

5. Ralston, A., Cox, B. J., Nishioka, N., Sasaki, H., Chea, E., Rugg-Gunn, P., ... \& Rossant, J. (2010). Gata3 regulates trophoblast development downstream of Tead4 and in parallel to Cdx2. Development, 137(3), 395-403.

6. World Health Organization. (1996). The world health report: 1996: fighting disease, fostering development. World Health Organization.

7. Everest, F. A. (2001). Master handbook of acoustics.

8. World Health Organization. (1992). World health statistics annual 1991. Weekly Epidemiological Record $=\quad$ Relevé épidémiologique hebdomadaire, 67(18), 133-133.

9. O Akinyemi, R., B Mukaetova-Ladinska, E., Attems, J., Ihara, M., \& N Kalaria, R. (2013). Vascular risk factors and neurodegeneration in ageing related dementias: Alzheimer's disease and vascular dementia. Current Alzheimer Research, 10(6), 642653.

10. Bhutta ZA. Current concepts in the diagnosis and treatment of typhoid fever. BMJ. 2006;333(7558):7882. doi:10.1136/bmj.333.7558.78

11. Osler, W. (1912). An address on high blood pressure: its associations, advantages, and disadvantages: Delivered at the Glasgow Southern Medical Society. British medical journal, 2(2705), 1173.

12. Crump, J. A., Luby, S. P., \& Mintz, E. D. (2004). The global burden of typhoid fever. Bulletin of the World Health Organization, 82, 346-353.

13. Alam, M., Höglund, C., \& Thorstrand, C. (1992). Longitudinal systolic shortening of the left ventricle: an echocardiographic study in subjects with and without preserved global function. Clinical physiology, 12(4), 443-452.

14. Rowe, J. W., \& Kahn, R. L. (1997). Successful aging. The gerontologist, 37(4), 433-440.

15. Asna, S. M. Z. H., Haq, J. A., \& Rahman, M. M. (2003). Nalidixic acid-resistant Salmonella enterica serovar Typhi with decreased susceptibility to ciprofloxacin caused treatment failure: a report from Bangladesh. Japanese journal of infectious diseases, 56(1), 32-33.

16. Renuka, K., Sood, S., Das, B. K., \& Kapil, A. (2005). High-level ciprofloxacin resistance in Salmonella enterica serotype Typhi in India. Journal of Medical Microbiology, 54(10), 999-1000. 
17. Ohsaki, Y., Shirakawa, H., Hiwatashi, K., Furukawa, Y., Mizutani, T., \& Komai, M. (2006). Vitamin K suppresses lipopolysaccharide-induced inflammation in the rat.Bioscience, biotechnology, and biochemistry, 70(4), 926-932.

18. Saha, S., Komaromy, M., Koepsell, T. D., \& Bindman, A. B. (1999). Patient-physician racial concordance and the perceived quality and use of health care. Archives of internal medicine, 159(9), 997-1004.

19. Poewe, W., Benke, T., Karamat, E., Schelosky, L., Wagner, M., \& Sperk, G. (1990). CSF somatostatinlike immunoreactivity in dementia of Parkinson's disease. Journal of neurology, neurosurgery, and psychiatry, 53(12), 1105.

20. Sehgal, J. L., Mandal, D. K., Mandal, C., \& Vadivelu, S. (1990). Agro-ecological regions of India. NBSS Publication, (24).

21. Furze, J. M., Rhodes, M. J., Parr, A. J., Robins, R. J., Withehead, I. M., \& Threlfall, D. R. (1991). Abiotic factors elicit sesquiterpenoid phytoalexin production but not alkaloid production in transformed root cultures of Datura stramonium. Plant cell reports, 10(3), 111-114.

22. Weber, G., \& Anand, L. (1990). Finite deformation constitutive equations and a time integration procedure for isotropic, hyperelastic-viscoplastic solids. Computer Methods in Applied Mechanics and Engineering, 79(2), 173-202.

23. Prakash, G. (1992). Postcolonial criticism and Indian historiography. Social Text, (31/32), 8-19.

24. Aha, D. W., Kibler, D., \& Albert, M. K. (1991). Instance-based learning algorithms. Machine learning, 6(1), 37-66.

25. Rani, P., \& Khullar, N. (2004). Antimicrobial evaluation of some medicinal plants for their antienteric potential against multi-drug resistant Salmonella typhi. Phytotherapy Research: An International Journal Devoted to Pharmacological and Toxicological Evaluation of Natural Product Derivatives, 18(8), 670-673.

26. Steinmann, J., Buer, J., Pietschmann, T., \& Steinmann, E. (2013). Anti-infective properties of epigallocatechin-3-gallate (EGCG), a component of green tea. British journal of pharmacology, 168(5), 1059-1073.

27. Reich, P. B., Hungate, B. A., \& Luo, Y. (2006). Carbon-nitrogen interactions in terrestrial ecosystems in response to rising atmospheric carbon dioxide. Annu. Rev. Ecol. Evol. Syst., 37, 611-636.

28. Cabrera, C., Artacho, R., \& Giménez, R. (2006). Beneficial effects of green tea-a review. Journal of the American College of Nutrition, 25(2), 79-99.

29. Xu, K., Zhang, S., Poese, B. A., \& Jow, T. R. (2002). Lithium bis (oxalato) borate stabilizes graphite anode in propylene carbonate. Electrochemical and Solid State Letters, 5(11), A259.

30. Fielding, N. G., Lee, R. M., \& Blank, G. (Eds.). (2008). The SAGE handbook of online research methods. Sage.

31. Hand, D. J., \& Till, R. J. (2001). A simple generalisation of the area under the ROC curve for multiple class classification problems. Machine learning, 45(2), 171-186.

32. Hassawi, D., \& Kharma, A. (2006). Antimicrobial activity of some medicinal plants against Candida albicans. J. Biol. Sci, 6(1), 109-114.

33. McKay, D. L., \& Blumberg, J. B. (2002). The role of tea in human health: an update. Journal of the American College of Nutrition, 21(1), 1-13.

34. McNaught, J. G. (1906). A Note on the Bacteriology of a Series of Cases of Sore Throat. BMJ Military Health, 7(3), 211-217.

35. Wang, P. C., Mori, T., Komori, K., Sasatsu, M., Toda, K., \& Ohtake, H. (1989). Isolation and characterization of an Enterobacter cloacae strain that reduces hexavalent chromium under anaerobic conditions. Applied and Environmental Microbiology, 55(7), 1665-1669.

36. Fukai, K., Ishigami, T., \& Hara, Y. (1991). Antibacterial activity of tea polyphenols against phytopathogenic bacteria. Agricultural and biological chemistry, 55(7), 1895-1897.

37. Akujobi, C. N. (2005). Antimicrobial susceptibility pattern of Klebsiella species from Ebonyi State University Teaching Hospital Abakaliki, Nigeria. Nigerian journal of clinical practice, 8(2), 90-93.

38. Durling, N. E., Catchpole, O. J., Grey, J. B., Webby, R. F., Mitchell, K. A., Foo, L. Y., \& Perry, N. B. (2007). Extraction of phenolics and essential oil from dried sage (Salvia officinalis) using ethanol-water mixtures. Food chemistry, 101(4), 1417-1424.

39. Alothman, M., Bhat, R., \& Karim, A. A. (2009). Antioxidant capacity and phenolic content of selected tropical fruits from Malaysia, extracted with different solvents. Food chemistry, 115(3), 785-788.

40. Naczk, M., \& Shahidi, F. (2006). Phenolics in cereals, fruits and vegetables: Occurrence, extraction and analysis. Journal of pharmaceutical and biomedical analysis, 41(5), 1523-1542.

41. Grigonis, A., Rutkūnienè, Ž., Kopustinskas, V., Babonas, G. J., \& Rèza, A. (2005). Investigation of optical properties of $\mathrm{aC}: \mathrm{H}$ films deposited from acetylene using direct ion beam deposition method. Vacuum, 78(2-4), 593-597.

42. Spigno, G., Tramelli, L., \& De Faveri, D. M. (2007). Effects of extraction time, temperature and solvent on concentration and antioxidant activity of grape marc phenolics. Journal of food engineering, 81(1), 200208.

43. Nićiforović, N., Mihailović, V., Mašković, P., Solujić, S., Stojković, A., \& Muratspahić, D. P. (2010). Antioxidant activity of selected plant species; potential new sources of natural antioxidants. Food and Chemical Toxicology, 48(11), 3125-3130.

44. Alothman, M., Bhat, R., \& Karim, A. A. (2009). Antioxidant capacity and phenolic content of selected tropical fruits from Malaysia, extracted with different solvents. Food chemistry, 115(3), 785-788.

45. Urszula, P., Jerzy, J., Sujka, M., \& Kowalski, R. (2015). Visualization of calcium and zinc ions in Saccharomyces cerevisiae cells treated with PEFs (pulse electric fields) by laser confocal microscopy. Food chemistry, 188, 16-23. 
46. Lunga, P. K., de Dieu Tamokou, J., Fodouop, S. P., Kuiate, J. R., Tchoumboue, J., \& Gatsing, D. (2014). Antityphoid and radical scavenging properties of the methanol extracts and compounds from the aerial part of Paullinia pinnata. Springerplus, 3(1), 1-9.

47. Nkogwe, C., Raletobana, J., Stewart-Johnson, A., Suepaul, S., \& Adesiyun, A. (2011). Frequency of detection of Escherichia coli, Salmonella spp., and Campylobacter spp. in the faeces of wild rats (Rattus spp.) in Trinidad and Tobago. Veterinary medicine international, 2011.

48. Muthusamy, D., Rao, S. S., Ramani, S., Monica, B., Banerjee, I., Abraham, O. C., ... \& Kang, G. (2006). Multilocus genotyping of Cryptosporidium sp. isolates from human immunodeficiency virus-infected individuals in South India. Journal of Clinical Microbiology, 44(2), 632-634.

49. Braak, H., Bohl, J. R., Müller, C. M., Rüb, U., de Vos, R. A., \& Del Tredici, K. (2006). Stanley Fahn Lecture 2005: The staging procedure for the inclusion body pathology associated with sporadic Parkinson's disease reconsidered. Movement disorders: official journal of the Movement Disorder Society, 21(12), 2042-2051.

50. Mandal, D., Kumar, R., Singh, D., \& Kumar, P. (2011). Growth and yield of direct-seeded rice (Oryza sativa) as influenced by sowing dates and weed management methods. International Journal of Bioresource and Stress Management, 2(3), 273-276.

51. Tripathi, R., \& Tiwari, G. N. (2005). Effect of water depth on internal heat and mass transfer for active solar distillation. Desalination, 173(2), 187-200.

52. Fonseca, M. A., Joaquinha, F., Messiya, F., Sweta, G., Pranali, N., \& Arvisha, P. (2014). Study of five poisonous plants. Journal of Economic and Taxonomic Botany, 38(3/4), 441-450.

53. Al-Jabri, N. N., \& Hossain, M. A. (2014). Comparative chemical composition and antimicrobial activity study of essential oils from two imported lemon fruits samples against pathogenic bacteria. Beni-Suef University Journal of Basic and Applied Sciences, 3(4), 247-253.

54. Yamaguchi, A., Uejo, F., Yoda, T., Uchida, T., Tanamura, Y., Yamashita, T., \& Teramae, N. (2004). Self-assembly of a silica-surfactant nanocomposite in a porous alumina membrane. Nature materials, 3(5), 337-341.

55. Turkmen, N., Velioglu, Y. S., Sari, F., \& Polat, G. (2007). Effect of extraction conditions on measured total polyphenol contents and antioxidant and antibacterial activities of black tea. Molecules, 12(3), 484-496.

56. Hamilton-Miller, J. M. (1995). Antimicrobial properties of tea (Camellia sinensis L.). Antimicrobial agents and chemotherapy, 39(11), 2375-2377.
57. Yam, T. S., Shah, S., \& Hamilton-Miller, J. M. T. (1997). Microbiological activity of whole and fractionated crude extracts of tea (Camellia sinensis), and of tea components. FEMS microbiology letters, 152(1), 169-174.

58. Cowell, S. J., Newby, D. E., Prescott, R. J., Bloomfield, P., Reid, J., Northridge, D. B., \& Boon, N. A. (2005). A randomized trial of intensive lipidlowering therapy in calcific aortic stenosis. New England Journal of Medicine, 352(23), 2389-2397.

59. Akinyemi, O. I., \& Dada, E. O. (2014). In vivo antityphoid activities and proximate analysis of ethanolic leaf extracts of Parquetina nigrescens. $J$ Pharm Biol Sci, 9(5), 115-112.

60. Kang, O. H., Jang, H. J., Chae, H. S., Oh, Y. C., Choi, J. G., Lee, Y. S., ... \& Kwon, D. Y. (2009). Antiinflammatory mechanisms of resveratrol in activated HMC-1 cells: pivotal roles of NF- $\kappa B$ and MAPK. Pharmacological research, 59(5), 330-337.

61. Coral, R. P., Constant-Neto, M., Silva, I. S., Barros, S., \& Jawetz, J. (2004). Influence of transposed stomach on cardiac function in patients with resected esophageal cancer. Diseases of the Esophagus, 17(4), 307-309.

62. Oboh, G., \& Oladunmoye, M. K. (2007). Biochemical changes in micro-fungi fermented cassava flour produced from low-and medium-cyanide variety of cassava tubers. Nutrition and health, 18(4), 355-367.

63. Stewart, S. L., Cardinez, C. J., Richardson, L. C., Thompson, T. D., Weir, H. K., Sabatino, S. A., ... \& Pechacek, T. F. (2008). Surveillance for cancers associated with tobacco use--United States, 1999. 2004.

64. Kumarnsit, E., Keawpradub, N., \& Nuankaew, W. (2006). Acute and long-term effects of alkaloid extract of Mitragyna speciosa on food and water intake and body weight in rats. Fitoterapia, 77(5), 339-345.

65. Koka, B. R., \& Prescott, J. E. (2008). Designing alliance networks: the influence of network position, environmental change, and strategy on firm performance. Strategic management journal,29(6), 639-661.

66. Cabrera, A., Collins, W. C., \& Salgado, J. F. (2006). Determinants of individual engagement in knowledge sharing. The International Journal of Human Resource Management, 17(2), 245-264.

67. Arakawa, H., Saribasak, H., Buerstedde, J. M., \& Haber, J. (2004). Activation-induced cytidine deaminase initiates immunoglobulin gene conversion and hypermutation by a common intermediate. PLoS biology, 2(7), e179.

Cite This Article: Mohammad Zahid Haider, Zesmin Fauzia Dewan, Md. Moniruzzaman Khan, Md. Enamul Kabir, Mir Muhammad Shoyeb Shahabuddin, Mohsena Aktar, Joyashish Roy, Farjana Akter (2022). Effect of Ethanol Extract of Camellia Sinensis on Salmonella Typhi Infection in Adult Male Rats. EAS J Pharm Pharmacol, 4(1), 7-21. 